\title{
What We Should Know About Village Tourism Destination Attributes?
}

\author{
Usep Suhud ${ }^{1 *}$, Mamoon Allan², Christian Wiradendi Wolor ${ }^{3}$ \\ ${ }^{1}$ Faculty of Economics, Universitas Negeri Jakarta, Indonesia \\ ${ }^{2}$ School of Archaeology and Tourism, University of Jordan \\ ${ }^{3}$ Faculty of Economics, Universitas Negeri Jakarta, Indonesia \\ *Corresponding author. Email: usuhud@unj.ac.id
}

\begin{abstract}
Through the Ministry of Tourism and Creative Economy, the Indonesian government mobilises villages to be more empowered. One of the initiatives that was initiated was the emergence of villages as tourism destinations. This study explores the attributes of tourism villages. The research was conducted in Jakarta by involving tourists who were selected using the convenient sampling method. A survey was designed with one central question: the participants' knowledge and perceptions about the attributes of the villages used as tourist destinations. The data were analysed using the method of content analysis. As a result, as perceived by participants, the attributes of village tourism are accessibilities, amenities, accommodations, and attractions.
\end{abstract}

Keywords: Destination attribute, Destination image, Village tourism, Tourism marketing

\section{INTRODUCTION}

One of the factors that stimulate the intention to visit a destination is the attributes of the destination. Some destinations have been rewarded with attractive natural attractions, others have created their attractions, and some have combined attractions created by nature with attractions created by humans. However, discussions about destinations are not just attractions but also other things, such as accommodation, accessibility, amenities, and activities that tourists can do.

The focus of the research in this study is the destination attribute of village tourism with an Indonesian background. There are 8.626 villages from 34 provinces in this archipelago. Every year, each village receives a fund more than IDR 1 billion (approximately USD 70,310.00). Some villages use this financial assistance to build roads, bridges, and other infrastructure. Others invest money by building village-owned enterprises (BUMDES). One of the businesses that the villages manage is a tourism village destination. Programs related to village tourism destinations receive special attention from the Ministry of Tourism and Creative Economy.

Previous studies have raised the topic of tourism destination attributes relating to wellness tourism, island tourism, health tourism, heritage tourism, sport and extreme-sport tourism, and urban tourism [1]-[4]. However, the attributes of tourism village destinations have received less scholarly attention. For this reason, this study aims to explore the attributes of tourism village destinations according to tourist perceptions.

The destination attribute is helpful, one of which is to segment the market [2]. The destination attribute could affect tourist satisfaction [5].

\section{LITERATURE REVIEW}

Destination attributes are a set of facilities and services provided and offered by a tourism destination to tourists, which become the destination's competitiveness [6]. Several studies raise the destination attribute with various approaches. For example, [7] state that destination attributes include accommodation, food and beverages, attraction, safety, and transportation. The accommodation will depend on availability, cleanliness, reliability, and promptness, lodging lost, and basic facilities. Furthermore, safety includes daytime, dark time, public transport, and accommodation. Transportation includes convenient, friendly, and reliable, local transport, available information, and easy to buy 
tickets. Furthermore, food and beverage refer to costly, tasty, halal food and hygiene. Attraction examples are historical, natural, religious, architectural, and festivals.

According to [8], destination attributes are hospitality, values, and activities. Hospitality refers to the friendliness of the host and willingness to share information about the destination where they live. Value is about the money tourists spend at the destination under what they get, including the availability of products typical of that place. Activities are the availability of exciting attractions with recreational attractions.

The destination attributes include attraction, accessibility, amenities, available packages, activities, and ancillary services [9]. Amenities include accommodation and catering facilities, retailing, and other tourist services. Available packages include prearranged packaged by intermediaries and principals, while ancillary services include banking, telecommunications, postal, and hospital services. Furthermore, in the context of snow sports, [10] mention that destination attributes are resort amenities and activities, snow sport conditions and quality, and price.

\section{METHODS}

This study was conducted in Jakarta, involving tourists who have travelled in the last six months. Participants were offered to fill out an online questionnaire, and they were selected using the convenient sampling method. The central question was about the attributes of a village as a tourism destination, and it was adapted from Bambang. Data were analysed using the content analysis method. Participants' answers were coded and grouped according to specific themes. Furthermore, the data were calculated using SPSS to see the frequency and percentage of each answer.

\section{RESULTS AND DISCUSSION}

\subsection{Participants}

Table 1 presents profile of the participants. There were 412 participants involved consisting of 245 women $(59.5 \%)$ and 167 men $(40.5 \%)$. One hundred seventy-eight participants (43.2\%) were unemployed, 172 participants (41.7\%) were employed. Furthermore, 58 participants $(14.1 \%)$ were selfemployed, and 4 (1\%) were retirees. Regarding marital status, 287 participants $(89.7 \%)$ were single, and 101 participants $(24.5 \%)$ were married. Furthermore, 12 participants $(2.9 \%)$ were separated or divorced, and the other $12(2.9 \%)$ were widows. Furthermore, 170 participants $(41.3 \%)$ were high school graduates, 160 participants $(38.8 \%)$ were undergraduate graduates, and 12 participants $(2.9 \%)$ were postgraduate graduates.

Table 1 Profile of participants

\begin{tabular}{|c|c|c|c|}
\hline \multicolumn{2}{|c|}{ Demographic profiles } & Frequency & Percent \\
\hline \multirow[t]{3}{*}{ Sex } & Male & 167 & 40.5 \\
\hline & Female & 245 & 59.5 \\
\hline & Total & 412 & 100.0 \\
\hline \multirow[t]{8}{*}{ Age } & $>50$ & 3 & 0.7 \\
\hline & $17-20$ & 84 & 20.4 \\
\hline & $21-25$ & 198 & 48.1 \\
\hline & $26-30$ & 40 & 9.7 \\
\hline & $31-35$ & 29 & 7.0 \\
\hline & $36-40$ & 22 & 5.3 \\
\hline & $41-45$ & 24 & 5.8 \\
\hline & $46-50$ & 12 & 2.9 \\
\hline \multirow{4}{*}{$\begin{array}{l}\text { Occupational } \\
\text { status }\end{array}$} & Employed & 172 & 41.7 \\
\hline & Unemployed & 178 & 43.2 \\
\hline & Self-employed & 58 & 14.1 \\
\hline & Retired & 4 & 1.0 \\
\hline \multirow{4}{*}{$\begin{array}{l}\text { Marital } \\
\text { status }\end{array}$} & Unmarried & 287 & 69.7 \\
\hline & Separated & 12 & 2.9 \\
\hline & Married & 101 & 24.5 \\
\hline & Widowed & 12 & 2.9 \\
\hline \multirow{5}{*}{$\begin{array}{l}\text { Level of } \\
\text { education } \\
\text { has been } \\
\text { completed }\end{array}$} & $\begin{array}{l}\text { Less than high } \\
\text { school }\end{array}$ & 21 & 5.1 \\
\hline & Diploma & 49 & 11.9 \\
\hline & Post graduated & 12 & 2.9 \\
\hline & Undergraduate & 160 & 38.8 \\
\hline & High school & 170 & 41.3 \\
\hline
\end{tabular}

\subsection{Village Tourism Destination Attributes}

Table 2 presents the findings of this study. The authors identified respondents' answers as belonging to four attributes of tourism destinations: accessibilities, amenities, accommodations, and attractions. For the accessibilities attribute, 375 participants $(91.02 \%)$ said that tourism village destinations must be accessible by two-wheeled vehicles. In Indonesia, motorbikes are very popular, especially among young people and those with low 
incomes. In addition, 79 participants (19.17\%) indicated that the destination was accessible by fourwheeled vehicles. Regarding amenities, 217 participants $(52.67 \%)$ indicated the need for a gift shop in tourism village destinations. In addition, 160 participants $(38.83 \%)$ stated that they also needed to provide a restaurant. Forty-two participants (10.19\%) paid attention to the parking lot. Furthermore, 280 participants $(67.96 \%)$ said that tourism village
In this study, amenities are represented by souvenir shops selling products typical of the villages visited, restaurants, industrial production processes standard of the villages visited, and parking lots. Biswas et al. [7] did not discuss amenities. However, they say that food and beverages need attention from managers. This attention is focused on, for example, price, taste, halal assurance for Muslim tourists, and hygiene. Talking about price, [8] discussed value for money.

Table 2. Image of village tourism destination

\begin{tabular}{c|l|c|c}
\hline No & Dimensions and Indicators & Total Freq. & Total Percent \\
\hline 1 & Accessibilities & & \\
\hline 2 & It can be accessed by two-wheeled vehicles. & 375 & 91.02 \\
\hline 3 & It has paved road access. & 2 & 0.49 \\
\hline 4 & It is four-wheeled vehicles accessible. & 9 & 19.17 \\
\hline 5 & It has paved road access. & 7 & 2.18 \\
\hline & Amenities & 217 & 1.70 \\
\hline 6 & It provides a gift shop. & 160 & 52.67 \\
\hline 7 & It provides restaurants or food stalls. & 2 & 38.83 \\
\hline 8 & It provides processed products from the village's typical & & 0.49 \\
\hline 9 & plantation/agriculture/ livestock. & 42 & 10.19 \\
\hline & Accommodation & & \\
\hline 10 & It provides lodging for tourists. & 280 & 67.96 \\
\hline & Attractions & & \\
\hline 11 & It has the entrepreneurial appeal of its citizens. & 4 & 0.24 \\
\hline 12 & It has artistic and cultural appeal. & 27 & 0.73 \\
\hline 13 & It has the charm of the village's typical handicrafts. & & 0.97 \\
\hline 14 & It has natural attractions (beaches/caves, lakes, rivers, waterfalls, etc.). & & \\
\hline
\end{tabular}

destinations need to provide accommodations for tourists. Finally, for attractions, 27 participants $(6.55 \%)$ revealed that village destinations must have natural attractions, such as beaches, caves, lakes, rivers, and waterfalls.

\subsection{Discussion}

This study found that accessibility is a vital attribute of a village destination. This finding is in line with what was excluded in the study of [9]. In this case, the village must pay attention to the quality of the road to the destination and so that it can be passed twowheeled and four-wheeled vehicles.
This study also reveals accommodation as one of the attributes of village destinations. According to [9], accommodation should be part of amenities. However, Biswas et al. [7] claim that accommodation is one of the critical attributes of a destination.

The fourth finding of this study is an attraction as an attribute of village destinations. In this regard, [7], [8], and [9] agree that attractions are essential to a destination. Furthermore, [8] and [9] reveal attractions as one of the attributes of a destination. However, in this study, the attraction was not part of the findings. 


\section{CONCLUSION}

Villages are exploring their potential to attract tourists. This study aims to explore respondents' perceptions of the attributes of tourism village destinations. The data for this study were collected using an online survey.

As a result, the authors were able to identify four destination attributes, including accessibilities, amenities, accommodations, and attractions. This method had limitations, mainly because the questions asked were open-ended, so the authors could not probe for undisclosed answers. However, based on the findings of this study, tourism village destination managers can make improvements and complement what tourists perceive as lacking.

Furthermore, this study expands the study of tourism village destinations, including rural tourism and community-based tourism. The authors recommend that future research be able to uncover other attributes of a tourism village destination, such as what activities tourists perceive as necessary. In addition, a lot of studies on tourist behaviour are still needed.

\section{AUTHORS' CONTRIBUTIONS}

Three authors wrote this article. The first author is responsible for article writing, data collection, and data processing. In addition, the second author contributed to completing the introduction and literature review, including proofreading and corresponding. The third author contributed to data collection and ended the discussion and conclusion sections.

\section{ACKNOWLEDGMENTS}

This study is part of a tourism village destination research project funded by the Ministry of Education and Culture, Republic of Indonesia.

\section{REFERENCES}

[1] S. W. Litvin and S. N. S. Ling, "The destination attribute management model: An empirical application to Bintan, Indonesia," Tour. Manag., vol. 22, no. 5, 2001, pp. 481-492.

[2] D. Dryglas and M. Salamaga, "Applying destination attribute segmentation to health tourists: A case study of Polish spa resorts," $J$. Travel Tour. Mark., vol. 34, no. 4, 2017, pp. 503514.
[3] P. Schofield, "Evaluating castlefeeld urban heritage park from the consumer perspective: Destination attribute importance, visitor perception, and satisfaction," Tour. Anal., vol. 5, no. 2-3, 2000, pp. 183-189.

[4] C. H. Zhang, Y. Ma, and K. Bai, "The asymmetric effect of urban destination attribute performance on tourist overall satisfaction: A case study of Beijing," Econ. Manag. J., vol. 2, no. 36,2014 , pp. 111-124

[5] T. Albayrak and M. Caber, "Destination attribute effects on rock climbing tourist satisfaction: An ssymmetric impact-performance analysis," Tour. Geogr., vol. 18, no. 3, 2016, pp. 280-296.

[6] M. Caber, T. Albayrak, and K. Matzler, "Classification of the destination attributes in the content of competitiveness (by revised importance-performance analysis)," J. Vacat. Mark., vol. 18, no. 1, 2012, pp. 43-56.

[7] C. Biswas, S. K. Deb, A. A.-T. Hasan, and M. S. A. Khandakar, "Mediating effect of tourists' emotional involvement on the relationship between destination attributes and tourist satisfaction," J. Hosp. Tour. Insights, 2020.

[8] M. Mahdzar, A. Shuib, S. Ramachandran, and S. H. M. Afandi, "The role of destination attributes and memorable tourism experience in understanding tourist revisit intentions," Am. J. Agric. Environ. Sci. (Tourism Environ. Soc. Manag. Sci., vol. 15, 2015, pp. 32-39.

[9] V. Gaffar, H. P. Wetprasit, and D. Setiyorini, "Comparative study of tourist characteristics on cultural heritage tourism sites: Survey on tourist in Indonesia and Thailand heritage sites," $J$. Tour. Hosp. Culin. Arts, vol. 3, no. 3, 2011, pp. 53-68.

[10] M. Mirehie and H. Gibson, "Destination attribute preferences of active snow sport tourists: Insights on female participants," in TTRA 2018 International Conference, 2018. 